\title{
Effect of Late Upward Tapping on the Productivity of the Metabolically Active Hevea brasiliensis Clone PB 260 in Southwestern Cote d'Ivoire
}

\author{
Kouakou N'guessan Kan Pulchérie ${ }^{1^{*}}$, Moro Affia Perpetue ${ }^{1}$, \\ Diarrassouba Moussa ${ }^{2}$, Lehi Irénée Malydie ${ }^{3}$, Konan Djézou ${ }^{4}, K_{\text {Koffi Antoine }}{ }^{\text {, }}$ \\ Kouakou Tanoh Hilaire ${ }^{1}$ and Obouayeba Samuel ${ }^{4}$ \\ ${ }^{1}$ Université Nangui Abrogoua, UFR Sciences de la Nature, Laboratoire de Biologie et Amélioration \\ des Productions Végétales, 01 BP 801 Abidjan 01, Côte d'lvoire, \\ ${ }^{2}$ Ecole Nationale Supérieure d'Abidjan, Physiologie Végétales, 08 BP 10 Abidjan 08, Côte d'Ivoire. \\ ${ }^{3}$ Laboratory of Biotechnology, Agriculture and Resource Development, UPR of Plant Physiology, \\ Option Agrophysiology, Faculty of Biosciences, Félix Houphouët Boigny University, 22 B.P. 582 \\ Abidjan 22, Côte d'Ivoire. \\ ${ }^{4}$ CNRA (Centre National de Recherche Agronomique), Station de Recherche de Bimbresso, 01 BP \\ 1536 Abidjan 01, Cote d'Ivoire. \\ ${ }^{5}$ UFR Agroforesterie, Université Jean Lorougnon, Laboratoire Amélioration de la Production, Agricole, \\ BP 150 Daloa, Côte d'lvoire. \\ Authors' contributions \\ This work was carried out in collaboration among all authors. All authors read and approved the final \\ manuscript. \\ Article Information \\ DOI: $10.9734 / A R R B / 2021 / v 36 i 1030440$ \\ Editor(s): \\ (1) Dr. Bechan Sharma, University of Allahabad, India. \\ Reviewers: \\ (1) Jongkers Tampubolon, HKBP Nommensen University, Indonesia. \\ (2) Irfan Martiansyah, Indonesian Institute of Sciences, Indonesia. \\ Complete Peer review History: https://www.sdiarticle4.com/review-history/75026
}

Original Research Article

Received 09 August 2021

Accepted 18 October 2021

Published 29 October 2021

\begin{abstract}
In order to evaluate the improvement of rubber productivity of rubber trees by late upward tapping. A study was conducted at SCASO (Société Civile Agricole du Sud-Ouest) on the PB 260 clone of the active metabolic class. The experimental set-up is a Fisher block design with eight treatments and three replications. The treatments compared were bled in reverse in the eleventh year of harvest, in quarter spiral every $3,4,5$ and 6 days, with stimulation frequencies of $6,8,10,12$ and 13 times a year. The parameters measured were rubber production, isodiametric growth, sensitivity to dry notching of trees and physiological profile. The results show that the different latex
\end{abstract}


harvesting technologies improve the rubber productivity of PB $260\left(5469 \mathrm{~kg} \cdot \mathrm{ha}^{-1} \cdot \mathrm{yr}^{-1}\right)$ with a low dry-nut rate $(1.2 \%)$ and satisfactory radial vegetative growth $\left(3.9 \mathrm{~cm} . \mathrm{yr}^{-1}\right)$. The physiological profile of the trees is balanced, but the treatments significantly influenced the different parameters except sucrose. Trees bled in $\mathrm{S} / 4 \mathrm{U}$ d3 gave better results due to their high yield with an acceptable dry notch rate. Late reverse tapping is therefore a good latex harvesting technology for improving rubber productivity after down tapping.

Keywords: Rubber tree; latex harvesting technology; productivity; upward tapping.

\section{INTRODUCTION}

The cultivation of rubber trees (Hevea brasiliensis), whether in the form of large industrial plantations or on the more modest scale of village plantations, is of considerable economic importance [1]. Unlike tuber and fruit crops, rubber trees are harvested by extracting their latex from the trunk of the tree, following a cut, incision or section in the bark tissue $[2,3]$. Its exploitation takes into account the physiological maturity of the tree which occurs in the 6th year of plantation [3-5]. Rubber latex is extracted over at least 30 years [6]. This duration of rubber exploitation is dependent on the latex harvesting technologies applied to the tree [7]. The management of a rubber plantation is based on the tapping panel management scheme of Gohet et al., [8]. It consists of harvesting latex for nine years at opening on the low or descending panel (descending tapping) and then from the tenth tapping year onwards on the high panel (reverse or ascending tapping), and this for four years. This first series of inverted tapping is followed by two years of downward tapping and one or two other series of inverted tapping alternated with downward tapping. The application of this tapping panel management scheme (downward and/or upward tapping) is likely to contribute to the improvement of rubber productivity in these plantations [8]. Furthermore, the work of Obouayeba et al., [9] and Dian et al., [10] shows that down tapping, on regenerated bark once, the first option for continuing the management of the tapping panel after nine years, is certainly productive, but it is less advantageous than inverted tapping, the second alternative, in terms of rubber productivity, vegetative growth, balance of the physiological profile and, above all, the economic longevity of the latex harvesting process. Indeed, their investigations in a nonindustrial rubber environment on the GT 1 clone of the moderate metabolic activity class showed that downward tapping under appropriate latex harvesting systems confers good yields, equal to or higher than the best yields in the world (1800 $\mathrm{kg}^{-1} \mathrm{ha}^{-1}$ year $\left.{ }^{-1}\right)$. According to these authors, the first four years of inverted tapping, immediately following downward tapping, show at least $25 \%$ higher rubber productivity than downward tapping. Furthermore, the work of Obouayeba, [11] and Diarrassouba, [7] indicated that the harvesting method applied to the different clones should take into account their metabolic characteristics. Thus, reverse bleeding from the tenth year onwards taking into account the latex harvesting system of the different metabolic activity classes of the clones would be advantageous. As it seems that the early harvesting of latex affects the physiological state of the rubber trees and their vegetative growth, what if reverse tapping was further delayed from its practice in the tenth year of tapping the rubber trees? To address this concern, this project envisages the practice of reverse tapping in the eleventh year, after ten years of down tapping.

The general objective of this study is to improve the productivity of rubber trees through late reverse tapping by taking into account the metabolic functioning of the laticifer cell. Specifically, the aim is to

- to evaluate the effect of late reverse tapping on rubber production and the average increase in girth of trees of the PB 260 clone

- to determine the influence of late reverse tapping on the dry tree rate and physiological profile of clone PB 260.

\subsection{Study Site}

The work for this study was carried out at the Société Civile Agricole du Sud-Ouest (SCASO). This company is located in the southwest of Côte d'Ivoire, between $4^{\circ} 40^{\prime}$ and $5^{\circ} 30^{\prime}$ north latitude and $6^{\circ} 20^{\prime}$ and $7^{\circ} 00^{\prime}$ west longitude, in the administrative region of Haut-Sassandra, precisely in the department of San-Pedro (Fig. 1). The department has a humid tropical climate with an average temperature of $26.2^{\circ} \mathrm{C}$ and an estimated average annual rainfall of $1469 \mathrm{~mm}$. The agricultural sector employs about $80 \%$ of the working population in this region. Cocoa, coffee, oil palm and rubber are the main crops grown in the region. 


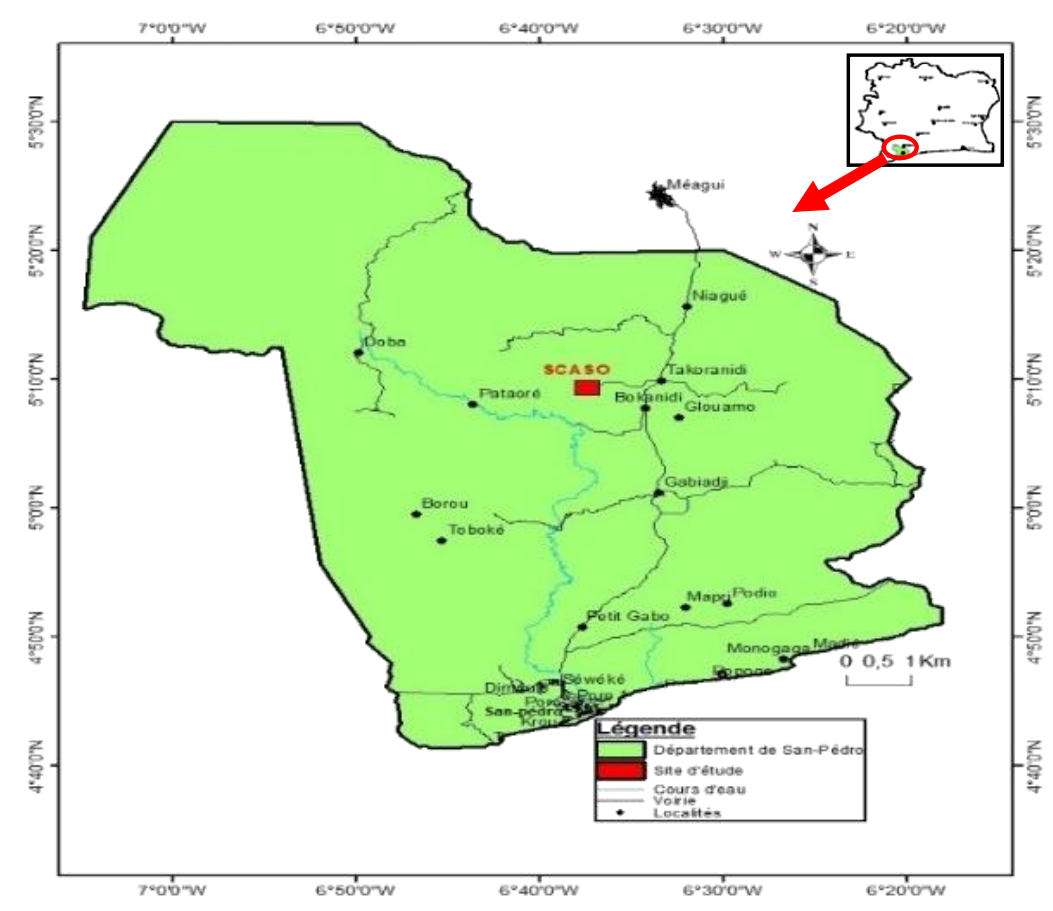

Fig. 1. Location of the study site [12]

\section{MATERIALS AND METHODS}

\subsection{Material}

\subsubsection{Plant material}

The plant material consisted of trees of Hevea brasiliensis clone PB 260. This clone is of the fast metabolic activity class and is one of the most planted clones in Côte d'lvoire as it is considered a high producer. This clone originates from Malaysia and is a cross of PB 5/51 X PB 49.

\subsubsection{Technical material}

The technical material consists of:

- tapping knife or gourd for tapping operations;

- ordinary scales for weighing the fresh rubber

- 10 to $15 \mathrm{ml}$ pillboxes for latex tapping;

- brushes and stimulant for stimulation operations;

- Oven for drying the collected latex;

- electronic precision balance $(0.001 \mathrm{~g})$

- test tubes, beakers, spatulas, electric stirrers, $\mathrm{pH}$ meter, hot plate, volumetric flasks, distilled water, ammonium molybdate, anthrone, dinitro - 2,2' - dithio 5 - 5'- dibenzoic acid (DTNB) for the preparation of reagents;
- spectrophotometer for reading the optical density (OD).

\subsection{Methods}

\subsubsection{Experimental design}

The experimental design was a Fisher block design of eight treatments with three replications (Fig. 2). The elementary plots each contained 21 trees selected on the basis of circumference and health status. This selection was made after the elimination of border trees, broken trees, trees with dry rot and those attacked by Rigidoporus microporus and their neighbors.

\subsubsection{Trial conduct and data collection}

Trial conduct: The latex harvesting technologies were applied to the different treatments 11 years after 10 years of top-down bleeding (Table 1) and data were collected over four years. The tapping was carried out respectively on panels $A$ (HO-1) in the first year, $\mathrm{B}(\mathrm{HO}-2)$ in the second year, $\mathrm{C}(\mathrm{HO}-3)$ in the third year and $\mathrm{D}(\mathrm{HO}-4)$ in the fourth year, taking into account the recommendation for tapping panel management of rubber trees in Côte d'lvoire, for a tapping frequency $\mathrm{d} / 4 \mathrm{dd} / 7 \mathrm{12 \textrm {m } / 1 2}$ of Gohet et al., [8] (Fig. 3). The international rating of rubber latex harvesting systems was used Vijayakumar et al., [13]. 


\begin{tabular}{|l|c|c|c|}
\hline Repetitions & I & II & III \\
\hline \multirow{4}{*}{ Treatments } & 1 & 3 & 8 \\
\cline { 2 - 4 } & 2 & 5 & 1 \\
\cline { 2 - 4 } & 3 & 8 & 4 \\
\cline { 2 - 4 } & 4 & 1 & 7 \\
\cline { 2 - 4 } & 5 & 6 & 2 \\
\cline { 2 - 4 } & 6 & 7 & 5 \\
\cline { 2 - 4 } & 7 & 4 & 6 \\
\cline { 2 - 4 } & 8 & 2 & 3 \\
\hline
\end{tabular}

Fig. 2. Fisher block design

Table 1. Treatments applied to the PB 260 clone during four years of experimentation in the southwest of the Ivory Coast

\begin{tabular}{|c|c|}
\hline $\mathbf{N}^{\circ}$ & Treatments \\
\hline 1 & $\mathrm{~S} / 4 \mathrm{U}$ d6 6d/7 ET 5\% Pa 1(1) 12/Y \\
\hline 2 & $\mathrm{~S} / 4 \mathrm{U} \mathrm{d} 6 \mathrm{6d} / 7$ ET $5 \%$ Pa 1(1) $15 / \mathrm{Y}$ \\
\hline 3 & $\mathrm{~S} / 4 \mathrm{U}$ d5 6d/7 ET 5\% Pa 1(1) 10/Y \\
\hline 4 & $\mathrm{~S} / 4 \mathrm{U}$ d5 6d/7 ET 5\% Pa 1(1) 12/Y \\
\hline 5 & $\mathrm{~S} / 4 \mathrm{U}$ d4 6d/7 ET 5\% Pa 1(1) 8/Y \\
\hline 6 & $\begin{array}{l}\mathrm{S} / 4 \mathrm{Ud} 46 \mathrm{~d} / 7 \mathrm{ET} 5 \% \mathrm{~Pa} 1(1) \text { 10/Y } \\
\text { (témoin) }\end{array}$ \\
\hline 7 & $\mathrm{~S} / 4 \mathrm{U}$ d3 6d/7 ET 5\% Pa 1(1) 6/Y \\
\hline 8 & S/4 Ud3 6d/7 ET 5\% Pa 1(1) 8/Y \\
\hline
\end{tabular}

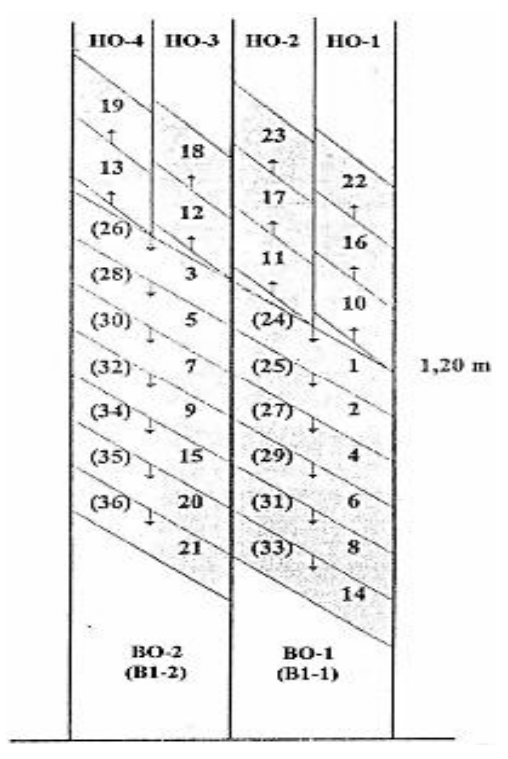

Fig. 3. Recommended tapping panel for rubber trees in Côte d'Ivoire, for tapping frequency $d / 46 d / 712 \mathrm{~m} / 12$ [8]

$\mathrm{S} / 4 \mathrm{U}$ : quarter spiral upward bleeding; $\mathrm{d} 3, \mathrm{~d} 4, \mathrm{~d} 5$ and d6: bleeding every three, four, five and six days; i.e. twice a week, three times a fortnight and once a week; $6 \mathrm{~d} 7$ : bleeding with one day off in the week, on Sunday; $\mathrm{n} / \mathrm{Y}$ : number of annual stimulations; Pa 1 (1): stimulation on a $1 \mathrm{~cm}$ wide strip, at a rate of $1 \mathrm{~g}$ of stimulant per tree.

- grey area: bark consumed during 36 years of latex harvesting from the tree;

$-1,2, \ldots .36$ : years of latex harvest;

- (..): latex harvesting on regenerated bark, already harvested once;

- $1.20 \mathrm{~m}$ above the ground: height of the lowest point of the tapping notch when the tree is tapped;

- descending arrows: bleeding in a descending half-spiral (S/2);

- Upward arrows: upward quarter-spiral tapping $(\mathrm{S} / 4 \mathrm{U})$;

- BO-1: Low tapping panel exploited in years 1, 2, 4, 6, 8 and 14 (virgin bark);

- BO-2: Low tapping panel harvested in years 3, $5,7,9,15,20$ and 21 (virgin bark);

- BI-1: Low bleeding panel exploited in years 24, 25, 27, 29, 31 and 33 (regenerated bark);

- BI-2: Low bleeding panel exploited in years 26, 28, 30, 32, 35 and 36 (regenerated bark);

- HO-1: High bleeding panel exploited in years 10, 16 and 22 (virgin bark);

- HO-2: High bleeding panel harvested in years 11,17 and 23 (virgin bark);

- HO-3: High bleeding panel harvested in years 12 and 18 (virgin bark);

- HO-4: High bleeding panel harvested in years 13 and 19 (virgin bark). 


\section{DATA COLLECTION AND TREATMENT}

\subsection{Production}

Rubber production data were collected following inverted quarter spiral tapping every 3, 4, 5 and 6 days, with stimulation frequencies of $6,8,10,12$ and 13 times per year. The stimulant product used was a mixture of Ethrel and palm oil. The stimulant paste contained 5\% ethephon (ET 5\%). The coagulum of all treatments collected, was weighed (weight of fresh matter, W.M.) and preserved. The transformation coefficient (T.C.), corresponding to the percentage of dry rubber in a given sample of fresh rubber, was used to calculate the dry rubber production (weight of dry matter, W.D.) by the following formula:

$$
\text { D.P. }=\text { D.P. } \times \text { C.T. }
$$

The weight of dry rubber was used to determine the production in $\mathrm{g} \cdot \mathrm{t}^{-1} \mathrm{t}^{-1}$ and then in $\mathrm{Kg} \cdot \mathrm{ha} \mathrm{a}^{-1}$ for a density of 555 trees/ha.

\subsection{Radial Vegetative Growth}

At the beginning of the trial and every year in January, the circumference of the trunk of the trees was measured at $1.70 \mathrm{~m}$ from the ground using a tape measure. The average annual increase in circumference was determined by the following relationship:

$$
\text { Grth }=\operatorname{Circ}_{n}-\operatorname{Circ}_{n-1}
$$

With Grth: average annual increase in circumference;

Circn: Circumference of the trees in the current season;

Circn-1: Circumference of trees from the previous season.

\subsection{Dry Notch Rate}

The rapid visual assessment method described by (Van De Sype, [14]) is used to describe the status of the dry notch for each bled tree. Each tree is assigned a number between 0 and 6 based on its latex flow. The percentage of completely dry trees in each treatment was determined by the following relationship:

$$
\text { Dry trees }(\%)=(\mathrm{n} 6+\mathrm{ES}) \times \mathrm{N}^{-1}
$$

n6: Number of trees in class 6; N: Total number of trees; ES: Number of trees with total dry notch

\subsection{Physiological Profile}

The latex microdiagnosis (LDM) consists in quantifying the four physiological parameters of the rubber latex which are dry extract (Ex. S), sucrose (Sac.), inorganic phosphorus (Pi) and thiol compounds (R-SH). These four parameters make it possible to assess the physiological state of the rubber tree, taking into account the reference values established by Jacob et al. [15]. The determination of the dry matter content (Ex.s) of the latex was carried out by the method described by Eschbach et al., [16]. The determination of sucrose (Sac), inorganic phosphorus (Pi) and thiol compounds (R-SH) was carried out by the methods of determination of Anthrone of Ashwell [17], ammonium molybdate of Taussky and Shorr [18] and dinitro - 2,2' - dithio - 5 - 5'- dibenzoic acid (DTNB) Boyne and Ellman [19] respectively.

\subsection{Statistical Analysis}

An analysis of variances and comparison of means was applied to the data for the different parameters, to observe or not possible significant differences between the latex harvesting systems applied to the PB 260 clone. This analysis was carried out with the XL-STAT software version 7.1. For values of $P \leq 0.05$, the difference is significant, but when $P>0.05$ the difference is not significant.

\section{RESULTS}

\subsection{Production}

The overall average annual dry rubber production expressed in $\mathrm{g} \cdot \mathrm{t}^{-1} \cdot \mathrm{t}^{-1}$ of clone PB 260 is $139 \mathrm{~g} \cdot \mathrm{a}^{-1} \cdot \mathrm{s}^{-1}$. The average annual production was statistically influenced by the latex harvesting technology applied and is high at low tapping intensity Table 2 . Indeed, the rubber productions obtained with treatments 1 to 6 are of the same order of magnitude. The same is true for treatments 7 and 8 (tapped at d3). However, their production is statistically lower than that of treatments 1 and 2 (tapped in $\mathrm{d} 6$ ), which are significantly equivalent to those of treatments 3 to 6 .

The average annual dry rubber yield expressed in kg.ha ${ }^{-1}$ year $^{-1}$ was $5469 \mathrm{~kg} \cdot$ ha. $^{-1}$ year ${ }^{-1}$ for all 
latex harvesting systems. Average annual yields varied significantly by latex harvesting system. The yields of latex harvesting systems 1 to 7 , with the exception of treatment 8 , are statistically equivalent. Those of treatments 1 and 2 are significantly lower than treatment 8 , whose yield is of the same order as those of treatments 3 to 7. The production in $\mathrm{kg} \cdot \mathrm{ha}^{-1} \mathrm{year}^{-1}$ followed a path opposite to that of the production in $\mathrm{g} \cdot \mathrm{a}^{-1} \cdot \mathrm{s}^{-1}$.

\subsection{Radial Vegetative Growth}

The overall mean annual increment for all treatments combined was $3.75 \mathrm{~cm}$. $\mathrm{yr}^{-1}$ Table 3.

The average annual growth was statistically different according to the treatment. It varied from 2.6 to $4.6 \mathrm{~cm} \cdot \mathrm{yr}^{-1}$, the increments of treatments 1 to 8 , with the exception of treatment 2 , were statistically of the same order of magnitude. The average annual increase of treatment 2 was statistically lower than those of treatments 5,7 and 8 but equivalent to those of the other treatments. Treatments that received fewer annual stimulations had a higher mean annual increase than those that received more stimulations.

\subsection{Dry Notching Rate}

The overall average dry notch rate presented in Table 4 is $1.2 \%$. It is very low and influenced by the different latex harvesting techniques applied to the trees. In general, the dry notch rate evolves with increasing tapping frequency. Treatment 8 bled in d3 coupled with 8 stimulations gave the highest dry notch rate $(2.4 \%)$, which is statistically of the same order of magnitude as treatments 4, 5, 6 and 7. The dry notching rates of treatments 1,2 and 3 are significantly lower than that of treatment 8 , but equivalent to the dry notching rates of treatments $4,5,6$ and 7.

Table 2. Average dry rubber production of PB260 clone trees subjected to different latex harvesting techniques

\begin{tabular}{|c|c|c|c|c|}
\hline & Treatments & $\begin{array}{l}\text { Numbers } \\
\text { of annual } \\
\text { tapping }\end{array}$ & $\begin{array}{l}\text { Production } \\
\text { g. } \mathrm{a}^{-1} \cdot \mathrm{s}^{-1}\end{array}$ & $\begin{array}{l}\text { Production } \\
\text { kg.ha' }{ }^{-1} \cdot \mathrm{an}^{-1}\end{array}$ \\
\hline 1 & $\mathrm{~S} / 4 \mathrm{U} \mathrm{d} 6 \mathrm{6d} / 7 \mathrm{ET} 5 \% \mathrm{~Pa} 1(1) 12 / \mathrm{Y}$ & 52 & $171,18 \pm 18,69$ a & $4940 \pm 608,6$ b \\
\hline 2 & $\mathrm{~S} / 4 \mathrm{Ud} 6$ 6d/7 ET $5 \%$ Pa 1(1)15/Y & 52 & $172 \pm 18,69 a$ & $4963 \pm 608,6 b$ \\
\hline 3 & $\mathrm{~S} / 4 \mathrm{U} \mathrm{d} 5 \mathrm{6d} / 7 \mathrm{ET} 5 \% \mathrm{~Pa} 1(1) 10 / \mathrm{Y}$ & 64 & $147,75 \pm 18,69 a b$ & $5248 \pm 608,6 a b$ \\
\hline 4 & $\mathrm{~S} / 4 \mathrm{U} \mathrm{d} 5 \mathrm{6d} / 7 \mathrm{ET} 5 \% \mathrm{~Pa} 1(1) 12 / \mathrm{Y}$ & 64 & $161,27 \pm 18,69 a b$ & $5728 \pm 608,6 a b$ \\
\hline 5 & $\mathrm{~S} / 4 \mathrm{Ud} 4$ 6d/7 ET 5\% Pa 1(1)8/Y & 78 & $121,75 \pm 18,69 a b$ & $5270 \pm 608,6 a b$ \\
\hline 6 & $\begin{array}{l}\mathrm{S} / 4 \mathrm{Ud} 46 \mathrm{~d} / 7 \mathrm{ET} 5 \% \mathrm{~Pa} 1(1) 10 / \mathrm{Y} \\
\text { (control) }\end{array}$ & 78 & $133,67 \pm 18,69 a b$ & $5786 \pm 608,6 a b$ \\
\hline 7 & $\mathrm{~S} / 4 \mathrm{Ud}$ 3 6d/7 ET 5\% Pa 1(1) 6/Y & 104 & $99,52 \pm 18,69 \mathrm{~b}$ & $5744 \pm 608,6 a b$ \\
\hline & $\mathrm{S} / 4 \mathrm{Ud} 36 \mathrm{~d} / 7 \mathrm{ET} 5 \% \mathrm{~Pa} 1(1) 8 / \mathrm{Y}$ & 104 & $105,25 \pm 18,69 b$ & $6075 \pm 608,6 \mathbf{a}$ \\
\hline \multicolumn{3}{|c|}{ Overall averages } & $139 \pm 26,7$ & $5469 \pm 393$ \\
\hline
\end{tabular}

Table 3. Average trunk circumference growth of PB 260 trees after four years of upward tapping

\begin{tabular}{|c|c|c|c|}
\hline & Treatments & $\begin{array}{l}\text { Numbers of } \\
\text { annual tapping }\end{array}$ & $\begin{array}{l}\text { Average circumference } \\
\text { growth }\left(\mathrm{cm} . \mathrm{an}^{-1}\right)\end{array}$ \\
\hline 1 & $\mathrm{~S} / 4 \mathrm{U}$ d6 6d/7 ET 5\% Pa 1(1)12/Y & 52 & $4,2 \pm 16,8 \mathrm{a}$ \\
\hline 2 & $\mathrm{~S} / 4 \mathrm{U} \mathrm{d} 6 \mathrm{6d} / 7$ ET $5 \%$ Pa $1(1) 15 / \mathrm{Y}$ & 52 & $4,6 \pm 6,2 \mathrm{a}$ \\
\hline 3 & $\mathrm{~S} / 4 \mathrm{U} \mathrm{d} 5 \mathrm{6d} / 7 \mathrm{ET} 5 \% \mathrm{~Pa} 1(1) 10 / \mathrm{Y}$ & 64 & $4,4 \pm 11,7 \mathrm{a}$ \\
\hline 4 & $\mathrm{~S} / 4 \mathrm{U} \mathrm{d} 5 \mathrm{6d} / 7$ ET $5 \% \mathrm{~Pa} 1(1) 12 / \mathrm{Y}$ & 64 & $3,7 \pm 1,2 \mathrm{ab}$ \\
\hline 5 & $\mathrm{~S} / 4 \mathrm{U} \mathrm{d} 46 \mathrm{~d} / 7 \mathrm{ET} 5 \% \mathrm{~Pa} 1(1) 8 / \mathrm{Y}$ & 78 & $3,6 \pm 4,43 a b$ \\
\hline 6 & $\begin{array}{l}\mathrm{S} / 4 \mathrm{Ud} 46 \mathrm{~d} / 7 \mathrm{ET} 5 \% \mathrm{~Pa} 1(1) 10 / \mathrm{Y} \\
\text { (control) }\end{array}$ & 78 & $3,7 \pm 8,16 a b$ \\
\hline 7 & $\mathrm{~S} / 4 \mathrm{Ud} 3 \mathrm{6d} / 7 \mathrm{ET} 5 \% \mathrm{~Pa} 1(1) 6 / Y$ & 104 & $3,6 \pm 4,6 a b$ \\
\hline 8 & $\mathrm{~S} / 4 \mathrm{Ud} 3$ 6d/7 ET 5\% Pa 1(1)8/Y & 104 & $2,6 \pm 1,4 b$ \\
\hline \multicolumn{2}{|r|}{ Overall averages } & & $3,75 \pm 2,1$ \\
\hline
\end{tabular}


Table 4. Dry notch rate of clone PB 260 after four years of upward tapping

\begin{tabular}{|c|c|c|c|}
\hline & Treatments & Numbers of annual tapping & Dry notch rate (\%) \\
\hline 1 & $\mathrm{~S} / 4 \mathrm{Ud}$ d6 6d/7 ET 5\% Pa 1(1)12/Y & 52 & $0,3 \mathrm{~b}$ \\
\hline 2 & $\mathrm{~S} / 4 \mathrm{U} \mathrm{d} 6 \mathrm{6d} / 7 \mathrm{ET} 5 \% \mathrm{~Pa} 1(1) 15 / \mathrm{Y}$ & 52 & $0,6 \mathrm{~b}$ \\
\hline 3 & $\mathrm{~S} / 4 \mathrm{U} \mathrm{d} 5 \mathrm{6d} / 7 \mathrm{ET} 5 \% \mathrm{~Pa} 1(1) 10 / \mathrm{Y}$ & 64 & $0,7 b$ \\
\hline 4 & $\mathrm{~S} / 4 \mathrm{U} \mathrm{d} 5 \mathrm{6d} / 7 \mathrm{ET} 5 \% \mathrm{~Pa}$ 1(1)12/Y & 64 & $1,4 a b$ \\
\hline 5 & $\mathrm{~S} / 4 \mathrm{U} \mathrm{d} 46 \mathrm{~d} / 7 \mathrm{ET} 5 \% \mathrm{~Pa} 1(1) 8 / \mathrm{Y}$ & 78 & $1,4 a b$ \\
\hline 6 & $\mathrm{~S} / 4 \mathrm{U}$ d4 6d/7 ET 5\% Pa 1(1)10/Y (control) & 78 & $1,5 a b$ \\
\hline 7 & $\mathrm{~S} / 4 \mathrm{U}$ d3 $6 \mathrm{~d} / 7 \mathrm{ET} 5 \% \mathrm{~Pa} 1(1) 6 / \mathrm{Y}$ & 104 & $1,3 a b$ \\
\hline \multirow[t]{2}{*}{8} & $\mathrm{~S} / 4 \mathrm{U}$ d3 6d/7 ET 5\% Pa 1(1)8/Y & 104 & $2,4 \mathrm{a}$ \\
\hline & Overall averages & & 1,2 \\
\hline
\end{tabular}

means with the same letters are not significantly different (Scheffe 5\%)

Table 5. Average values of physiological parameters of clone PB 260 subjected to different latex harvesting technologies after four years of upward tappind

\begin{tabular}{|c|c|c|c|c|c|c|}
\hline & \multirow[b]{2}{*}{ Treatments } & \multirow{2}{*}{$\begin{array}{l}\text { Numbers of } \\
\text { annual } \\
\text { tapping }\end{array}$} & \multicolumn{4}{|c|}{ Parameters physiologies } \\
\hline & & & $\begin{array}{l}\text { DRC } \\
\text { (\%) }\end{array}$ & $\begin{array}{l}\text { Suc } \\
\left(\mathrm{m} . \mathrm{mol}^{-1} \mathrm{I}^{-1}\right)\end{array}$ & $\begin{array}{l}\mathrm{Pi} \\
\left(\mathrm{m} . \mathrm{mol}^{-1} \mathrm{I}^{-1}\right)\end{array}$ & $\begin{array}{l}\text { R-SH } \\
\left(\mathrm{m} . \mathrm{mol} . \mathrm{I}^{-1}\right)\end{array}$ \\
\hline 1 & $\mathrm{~S} / 4 \mathrm{U}$ d6 6d/7 ET 5\% Pa 1(1)12/Y & 52 & $57,45 \pm 1,10 a$ & $7,86 \pm 1,50 \mathrm{a}$ & $20,37 \pm 1,24 a b$ & $0,64 \pm 0,10 a b$ \\
\hline 2 & $\mathrm{~S} / 4 \mathrm{U}$ d6 6d/7 ET 5\% Pa 1(1)15/Y & 52 & $58,02 \pm 1,10 a$ & $8,75 \pm 1,50 a$ & $20,58 \pm 1,24 a b$ & $0,65 \pm 0,10 a b$ \\
\hline 3 & $\mathrm{~S} / 4 \mathrm{U}$ d5 6d/7 ET 5\% Pa 1(1)10/Y & 64 & $53,93 \pm 1,10 a b$ & $8,37 \pm 1,50 \mathrm{a}$ & $20,92 \pm 1,24 a b$ & $0,56 \pm 0,10 b$ \\
\hline 4 & $\mathrm{~S} / 4 \mathrm{U}$ d5 6d/7 ET 5\% Pa 1(1)12/Y & 64 & $55,12 \pm 1,10 a b$ & $8,68 \pm 1,50 \mathrm{a}$ & $21,53 \pm 1,24 \mathrm{a}$ & $0,75 \pm 0,10 a b$ \\
\hline 5 & $\mathrm{~S} / 4 \mathrm{U}$ d4 6d/7 ET 5\% Pa 1(1)8/Y & 78 & $50,83 \pm 1,10 a b$ & $7,89 \pm 1,50 \mathrm{a}$ & $17,81 \pm 1,24 \mathrm{~b}$ & $0,71 \pm 0,10 a b$ \\
\hline 6 & $\mathrm{~S} / 4 \mathrm{Ud} 46 \mathrm{~d} / 7 \mathrm{ET} 5 \% \mathrm{~Pa} 1(1) 10 / \mathrm{Y}$ & 78 & $52,27 \pm 1,10 a b$ & $9,45 \pm 1,50 \mathrm{a}$ & $18,64 \pm 1,24 a b$ & $0,76 \pm 0,10 a b$ \\
\hline 7 & $\mathrm{~S} / 4 \mathrm{U}$ d3 6d/7 ET 5\% Pa 1(1) 6/Y & 104 & $49,68 \pm 1,10 b$ & $7,95 \pm 1,50 \mathrm{a}$ & $19,53 \pm 1,24 a b$ & $0,81 \pm 0,10 a b$ \\
\hline \multirow[t]{2}{*}{8} & $\mathrm{~S} / 4 \mathrm{U} \mathrm{d} 3 \mathrm{6d} / 7 \mathrm{ET} 5 \% \mathrm{~Pa} 1(1) 8 / \mathrm{Y}$ & 104 & $50,52 \pm 1,10 a b$ & $9,41 \pm 1,50 \mathrm{a}$ & $20,52 \pm 1,24 a b$ & $0,89 \pm 0,10 \mathrm{a}$ \\
\hline & Overall averages & & 53,54 & 8,53 & 19,98 & 0,72 \\
\hline
\end{tabular}

In the same column, means with the same letters are not significantly different (Scheffe $5 \%$ )

DRC : Dry extract ; Suc : Sucrose ; Pi : Inorganic phosphorus; $R$-SH: Thiol group. 


\subsection{Physiological Profile}

The average annual dry extract rate for the four years of reverse tapping, for all treatments combined, was $53.54 \%$. This rate is very high (> $43 \%$ reference value) overall and regardless of the latex harvesting technology applied (Table 5). The significantly higher rates of 58.02 and $57.45 \%$ were obtained in treatments 1 and 2 bled in d3 respectively. These rates are equivalent to those of treatments 3 to 8 .

Analysis of the mean annual sucrose content of clone PB260 reveals that the treatments applied to the trees did not have a significant effect on the sucrose content. Overall, the sucrose content was moderate or average $\left(8.53 \mathrm{~m}\right.$. mol. $\left.\mathrm{I}^{-1}\right)$ and ranged from 6 to $9 \mathrm{~m}$. mol. $\mathrm{I}^{-1}$. However, it varied from 7.89 to $9.41 \mathrm{~m}$. mol. $\mathrm{I}^{-1}$.

The average annual inorganic phosphorus content of latex for all latex harvesting technologies combined (19.98 m. mol. $\left.{ }^{-1}\right)$ is high and characteristic of clones with active or rapid metabolism. It varied significantly according to the treatment. The $\mathrm{Pi}$ content of latex from treatment $4\left(21.53 \mathrm{~m}\right.$. mol. $\left.\mathrm{I}^{-1}\right)$ is statistically higher than that of treatment $5\left(17.81 \mathrm{~m}\right.$. mol. $\left.{ }^{-1}\right)$ which has the lowest $\mathrm{Pi}$ content in latex. The average annual $\mathrm{Pi}$ content of latex in treatments 4 and 5 is significantly and respectively of the same order of magnitude as that of treatments 1 , 2, 3, 6, 7 and 8.

The average annual content of thiol groups (R$\mathrm{SH}$ ) in latex for all latex harvesting technologies combined $\left(0.72 \mathrm{~m} . \mathrm{mol}^{-\mathrm{I}^{-1}}\right)$ is good. It varied significantly according to the treatment. The latex SHR content of treatment $8\left(0.89 \mathrm{~m}\right.$. mol. $\left.\mathrm{I}^{-1}\right)$ is statistically higher than that of treatment $3(0.56$ $\mathrm{m}$. mol..$^{-1}$ ) which has the lowest latex SHR content. The average annual latex $\mathrm{SH}-\mathrm{R}$ content of treatments 3 and 8 is significantly and respectively of the same order of magnitude as that of treatments $1,2,4,5,6$ and 7 .

\section{DISCUSSION}

The average annual rubber production expressed in $g \cdot \mathrm{t}^{-1} \cdot \mathrm{t}^{-1}$ of 139 is good, but it increases with the reduction of the tapping intensity. The longer the time in days between two consecutive tapping's, the higher the rubber production. Thus, tapping frequency has an effect on production. This is especially true since the closer the consecutive tapping's, the less time the Laticifer cells have to regenerate latex in the vessels, and the more production is negatively affected. This result confirms the work of Obouayeba et al., [20] and Traoré, [21]. Indeed, these authors established that there is a relationship between tapping frequency and rubber production expressed in $g \cdot \mathrm{t}^{-1} \cdot \mathrm{t}^{-1}$. According to them, the high rubber production obtained with less frequent tapping can be explained by the longer time between two consecutive tapping's, which allows for better regeneration of the laticifers contents [4]. Therefore, trees tapped once a week, six working days out of seven ( $d 66 \mathrm{~d} / 7$ : treatment 1 and 2) gave the highest production of dry rubber per tapping in contrast to twice a week tapping which gave the lowest productions.

Furthermore, the dry rubber yield expressed in kg.ha-1 year- 1 is also good and tends to increase with the intensification of tapping, so that the closer the tapping's are to each other (d3) the higher the rubber production. These results are in agreement with the work of Diarrassouba, [7]., Obouayeba et al., [2]. et Adou, [22]. According to these authors, the more intense the tapping, the higher the production per hectare. The lacticogenic function of the trees is thus activated and/or exalted. Indeed, bleeding itself stimulates latex production by endogenous ethylene induced by bleeding stress $[20,23,4]$.

The highest average annual girth increments were found in the treatments with the lowest rubber yields. In fact, the frequency d3 which gave the highest yield has the lowest increase. This result reflects the fact that latex production is in competition with the primary biomass development of the tree in its process, as far as the orientation of the photoassimilates is concerned. This means that the greater the latex production, the more the tree growth is reduced. These results corroborate those of several authors such as Gohet et al., [23], Obouayeba et al., [20], and Obouayeba [3].

The susceptibility of trees to dry notching is a likely expression of physiological fatigue of the Laticifer tissues [23]. The rate of trees affected by dry notching in clone PB 260 in this study was relatively low compared to those obtained in the work of Traoré, [21] in reverse bleeding in clone PB 235 of the same metabolic activity class as PB 260. This result indicates that in terms of dry notching susceptibility, the clones are not expressed in the same way, although they are of the same metabolic class $[23,22]$. Also, this result confirms the good functioning of the 
Laticifer cells, which are a priori protected by the good increased availability of intralacticifer sugar and SHR within the latex in clone PB 260.

The average annual dry extract content of latex from trees bled in late reverse was very high in clone PB 260. This good level of dry extract content reflects good regeneration of the exported latex after tapping as shown by several authors $[2,22]$. The rubber yields of the different latex harvesting technologies are very high. Also, the best rates obtained at frequencies $\mathrm{d} 5$ and $\mathrm{d} 6$ are due to the fact that the time interval between two bleedings influences the in situ regeneration of latex. The longer the interval, the better and more complete the in situ regeneration and the higher the dry rubber content [7].

The average annual sucrose content of the latex was either average or high depending on the tapping frequency. The presence of this high amount of sucrose in the latex is a sign of high production potential of the trees due to the good availability of rubber raw material in the laticifers $[22,23]$.

Inorganic phosphorus levels in tree latex are high regardless of treatment. They reflect a good availability of the metabolic energy necessary for the activation of the metabolism within the laticifers. This is an intrinsic characteristic of this clone according to the clonal typology of metabolic functioning of the laticogenic system [23]. Indeed, as shown in the work of Lacote et al., [6], metabolic activation is governed by intrinsic energy. Thus, in this study, the crosslinked metabolism would be more activated in d3-bleeding rubber trees.

The levels of thiol groups in the latex were globally of an average level. These latex $\mathrm{R}-\mathrm{SH}$ values indicate an acceptable level of biological protection of the lutoids and a certain stability of the rubber latex, as shown by the work of Coulibaly et al., [24] and Dick et al., [25] on the GT1, PB 217, PB 235 and PB 260 clones respectively.

From the above, it can be seen that the practice of inverted bleeding therefore helps to improve tree productivity. However, for better protection of the trees, the latex harvesting technologies applied to the trees must be taken into account.

\section{CONCLUSION}

At the end of this study, which aimed to evaluate the effect of late reverse tapping on rubber productivity of the PB 260 clone, we can conclude that late upward tapping improves rubber productivity. Indeed, our results indicate a good rubber productivity of the rubber trees in late upward tapping, the existence of a weak competition between growth and rubber production and also the obtaining of a low dry tree rate. This confirms that the delay in reverse tapping relative to its practice in the tenth year of tapping does not negatively affect the trees. In addition, the different technologies are good, although the d3 tapping frequency shows the best expression in this trial.

\section{DISCLAIMER}

The products used for this research are commonly and predominantly use products in our area of research and country. There is absolutely no conflict of interest between the authors and producers of the products because we do not intend to use these products as an avenue for any litigation but for the advancement of knowledge. Also, the research was not funded by the producing company rather it was funded by personal efforts of the authors.

\section{COMPETING INTERESTS}

Authors have declared that no competing interests exist.

\section{REFERENCES}

1. Dusotoit CA, Physiological and molecular characterizations of sugar and polyol transporters of laticiferous cells in "Hevea brasiliensis", in relation to latex production. Thesis. Blaise Pascale University, Auvergne, France. 2012;160.

2. Obouayeba S, Boko MCA, Soumahin EF, Elabo AAE, Dea GB, Badou EA, Christophe Kouamé, Zéhi B and Kéli ZJ, Natural rubber-based intercropping systems in Côte d 'Ivoire: A review of forty years of work. Rub Sc. 2016;28(3):211226.

3. Obouayeba S, Contribution to the determina-tion of the physiological maturity of the bark for the bleeding of Hevea brasiliensis. Muell. Arg: Openness standards. Doctoral thesis. Agrophysiology. University of Cocody-Abidjan, Ivory Coast. 2005;225:

4. Soumahin EF, Optimization of rubber farming systems by reducing bleeding intensities. Doctoral thesis, Cocody University, Abidjan, Ivory Coast. 2010;149. 
5. Coulibaly LF, Traoré MS, Kouamé NMT. Incidence of High Frequencies of Hormonal Stimulation on Two Descending Bleeding Regimes of Clone PB 215: Low (d6) and Moderate (d4), South-East of Côte D ' Ivory. European Scientific Journal May 2018 edition. 2018;14(15).

ISSN: 1857 - 7881 (Print) e - ISSN 1857 743. v1 4n15p499.

6. Lacote R, Gabla O, Obouayeba S, Eschbach JM, Rivano F, Dian K, Gohet E. Long term effect of ethylene stimulation on the yield of rubber trees linked to latex cell biochemistry, Field Crops Research. 2010;115: 94-98.

7. Diarrassouba M. Exploitation systems adapted to Hevea brasiliensis clones of moderate and fast activity classes. Single Doctorate Thesis, University of Cocody, Abidjan (Ivory Coast). 2013;173.

8. Gohet $E$, Lacrotte $R$, Obouayeba $S$, Commere J. Tapping systems recommended in West Africa. In Proced Rubber Research Institute of Malaya Rubber Growers' Conference. 1991;235254.

9. Obouayeba $S$, Soumahin EF, Boko AMC, Dea GB, Dian K, Gnagne YM. Improvement of Productivity of Rubber Trees in Smallholding by the Introduction of Upward Tapping in the South-East of Côte d'Ivoire. J. Rubb. Res. 2008;11(3): 163-170.

10. Dian K, Okoma MK, Koffi KE, Pokou DN, Kan MK. Effect of etephon stimulation frequency in downward tapping on the production potential in upward tapping among PB 260 clone of Hevea brasiliensis in Ivory coast. Inter. J. Agro. And Agri. Research. 2016;8(2):51-63.

11. Obouayeba $S$, Soumahin EF, Dobo $M$, Lacotte R, Gabla O, Doumbia A. Agronomic performance of clone IRCA111 of Hevea brasiliensis under different frequencies of tapping and stimulation in South-West Côte d'Ivoire. J of Rubbres. 2009;12(2):93-102.

12. Lehi MI, Djezou K, Elabo AAE, Ballo EK, Guinagui NB, Koné B, Koné D, Zouzou M, Obouayeba S. Metabolic partition between radial vegetative growthand rubber production of Hevea brasiliensis clones of different metabolic classes, bled at unstimulated d4 frequency in Côte d'Ivoire. IJAAS. 2020;2(3):207-214.

13. Vijayakumar KR, Gohet E, Thomas KU, Xiaodi W, Sumarmadji, Rodrigo L, Thanh
DK, Sopchoke P, Karunaichamy K, Said MAM. Revised international notation for latex production technology. International Rubber Research Development Board. 2009;19.

14. Van De Sype $H$. The dry cut syndrome in Hevea brasiliensis, evolution, agronomical and physiological aspects. In C. R. Coll. IRRDB. Physiology, Operation, Improvement. Hevea. IRCA-CIRAD, Montpellier edition. 1984;227-249.

15. Jacob JL, Serres E, Prevot JC, Lacrotte R, Clement-Vidal A, Eschbach JM, D'Auzac J. Development of latex diagnostics. Agritrop. 1988;12:97-118.

16. Eschbach JM, Tupy J. et Lacrotte R, 1986. Photosynthetate allocation and productivity of latex vessels in Hevea brasiliensis. Biologia Plantarum, 28: 321- 328.

17. Ashwell G, Colorimetric analysis of sugar. Methods in Enzymology, 1957, 3: 73-105.

18. Taussky $\mathrm{HH}$. and Shorr E, A micro colorimetric method for the determination of inorganic phosphorus. J. Biol. Chem. 1953, 202: 675 - 685.

19. Boyne AF. and Ellman GI, A methodology for analysis of tissue sulphydryl components. Analytical Bilochemistry. 1972, 46: 639-653.

20. Obouayeba S., Boa D. and Keli Z. J. Adequacy between quantity of stimulating paste and production of caou Hevea brasiliensis in the south-eastern part of the Ivory Coast. Tropicultura, 1996, 14 (2): 5458.

21. Traoré MS, Effects of different annual frequencies of ethylenic stimulation on the agrophysiological parameters of Hevea brasiliensis Müll clones. Arg. (Euphorbiaceae), PB 235, PB 260, GT 1 and PB 217 cultivated in the south-east of Côte d'Ivoire. Doctoral thesis, Félix Houphouët-Boigny University. Abidjan, Ivory Coast, 2014,150 p.

22. Adou YBC, Effect of latex harvesting technologies on rubber production from hevea [Hevea brasiliensis Muell. Arg. (Euphorbiaceae)] and contribution of latex micro diagnostics to the modern management of rubber plantations in Côte d'Ivoire. Single Doctorate Thesis, Nangui Abrogoua University (Ivory Coast), 2019, $124 \mathrm{p}$.

23. Gohet E, Prévôt JC, Eschbach JM, Clément $A$. and Jacob JL, Clone, growth and stimulation, factors of latex production. Plant., Rech., Dev. 1996;3(1):30-38. 
24 Coulibaly LF, Traore MS, Soumahin EF, Obouayeba S, Keli JZ. Incidence of bleeding frequencies $\mathrm{d} 3, \mathrm{~d} 4$ and $\mathrm{d} 6$, at low hormonal stimulation regimes, on the descendant panel of the PB 235 rubber clone in Côte d'Ivoire. International journal of Biological and Chemical Science. 2017; 11(4):1655-1668.

ISSN 1991 -8631 (Print), ISSN 1997-342X

25 Dick EA, Traoré MS, Elabo AEA, Soumahin EF, Assi EGM, Atsin OGJ, Alle YJ, N'guessan AEB, Kouamé C,
Obouayeba S. Effects of different annual frequencies of ethylenic stimulation on the agrophysiological parameters and Sensitivity to the dry notch of Hevea brasiliensis in the South-East of Côte d'Ivoire: case of the PB 235 and PB 260 clones of the fast activity class. Int. J. Biol. Chem. Sci. 2014;8(3):956-974.

DOI:https://www.ajol.info/index.php/ijbcs/ar ti cle / viewFile / 108991/98780. the references have been updated

(0) 2021 Pulchérie et al.; This is an Open Access article distributed under the terms of the Creative Commons Attribution License (http://creativecommons.org/licenses/by/4.0), which permits unrestricted use, distribution, and reproduction in any medium, provided the original work is properly cited. 